REDAKTIONEN

3 Forord

Klima, magt, modstand

REDAKTIONEN

9 Introduktion til Amy Riddle: "Petrofiktion og politisk økonomi i den sene fossile kapitals tidsalder"

AMY RIDDLE

13 Petrofiktion og politisk økonomi i den sene fossile kapitals tidsalder

IBEN ENGELHARDT ANDERSEN

39 Utopisk slægtskab i udryddelsens tid

MADS EJSING

59 Antropocæne fortællinger

Mindre end én, flere end mange

ELISABETH FRIIS \& TORSTEN BØGH THOMSEN

77 Glo ikke så romantisk!

Økolitterære former

STEFAN GAARSMAND JACOBSEN

101 Undtagelsesmodstand

Klimanød, undtagelsestilstand og aktivistisk temporalitet

THOMAS ROSENDAL NIELSEN

121 Mennesket i myreperspektiv

Secret Hotels Vandringsforelæsning om Myrer som antropocæn poetik

GREGERS ANDERSEN

141 Antropocæn og automatiseringen af adfærd

En kritik af det liberale Danmarks teknologioptimisme

Anmeldelser

\title{
ELLEN KREFTING
}

159 Ordenes politikk

Anmeldelse af Jonas Ross Kjærgård: Reimagining Society in Eighteenth-Century French Literature. Happiness and Human Rights 


\section{REDAKTIONEN}

Elisabeth Friis, Signe Leth Gammelgaard, Stefan Gaarsmand Jacobsen Søren Mau og Torsten Bøgh Thomsen

\section{TORSTEN ANDREASEN}

167 Gæld, skyld og en manglende kritik af volden

Anmeldelse af Mikkel Thorup: Du Skylder! Om moralsk \& økonomisk gæld

\section{FORORD}

Klima, magt, modstand

Hvordan bremser vi menneskeskabte klimaforandringer? Det er ikke mange år siden, man talte om, at klimastof og grønne dagsordner bare ikke var særlig sexede, at det var svært at fange og fastholde folks opmærksomhed på problemstillinger, der ikke som sådan var nyhedsstof. Sådan er det ikke længere. Klimabevægelserne er i den grad lykkedes med at gøre klimaet til et så væsentligt politisk emne, at stort set alle politiske aktører kæmper om at fremstille sig selv som de grønneste. Under sidste folketingsvalg proklamerede Mette Frederiksen dette som Danmarks første klimavalg, og under debatterne markerede alle på nær et enkelt parti sig som det mest grønne. Flyskam er i Sverige nu blevet så udbredt, at man kan registrere det statistisk med et fald i antallet af flyrejser på 3,5 procent sidste år. Den ekstremt varme sommer i 2018 kombineret med dette års påfaldende lune vinter og hyppige nyhedshistorier om oversvømmelser, skovbrande og lignende ekstreme klimaforhold gør, at det tidligere så abstrakte fænomen global opvarmning nu virker højaktuelt for de fleste, og EUs nye initiativ Green Deal viser ønsket om i det mindste at signalere ændringer i størrelsesorden med Roosevelts nye samfundskontrakt fra 1930'ernes USA.

Trods al denne palaver sker der alt for lidt, og det går alt for langsomt. Klimabevægelserne presser på for radikal forandring, men trægheden og 
modstanden blandt politiske og økonomiske eliter er massiv, og for hver dag der går, bliver det mere og mere tydeligt, at løsninger må skabes på trods af - og ikke igennem - den gamle verdens hierarkier og magtstrukturer.

I dette nummer af $\mathrm{K} \& \mathrm{~K}$ ønsker vi at undersøge klimaet især i dets sociale kontekst, og at spørge hvad de humanistiske videnskabers bidrag kan og gør i forhold til denne dagsorden, samt hvilke forbindelser der kan tænkes imellem kunst, litteratur og politik, når det kommer til spørgsmålet om klimaforandringerne og disses samfundsmæssige konsekvenser. Selvom stort set samtlige politiske partier mener, at de selv danner fortrop på den grønne front, er det oplagt, at de ikke foreslår samme politiske løsninger på problemerne. Klimaet har vist sig som en prisme for politiske ideologier, hvor forskellige aktører taler deres egen sag gennem denne fælles dagsorden. For neoliberale kræfter er det blevet endnu en anledning til at foreslå markedskræfterne som en central del af løsningen, og for dele af den ekstreme højrefløj har opmærksomheden på klima og miljø givet anledning til at reformulere gamle fascistiske ideer om et naturligt bånd mellem folket og jorden som en økologisk vision. Klimapolitik er blevet en arena for kampe omkring demokrati og videnskab, kampe om at afgøre, hvem der egentlig bærer ansvaret, og hvem der har magten til at skabe forandring.

Men disse spørgsmål udspiller sig også på teoretisk plan. Igennem længere tid er der blevet slået til lyd for, at vores naturforståelser er utilstrækkelige til at tage hånd om disse problemer. Teorier om den antropocæne tidsalder, aktør-netværks-teori, nymaterialisme og økokritik m.fl. skyder med skarpt mod idéen om mennesket som altings målestok og taler for en forståelse af forbundethed og ansvarlighed overfor det mere-end-menneskelige. Overfor dette står visse dele af øko-marxismen, som i modsætning til nymaterialismen og aktør-netværks-teori mener, at skellet mellem menneske og natur er afgørende for den rette forståelse af menneskets andel i miseren, og som i modsætning til begrebet om det antropocæne påpeger, at det ikke er mennesket eller menneskeheden, der er skyld i klimaforandringerne, men derimod en historisk specifik måde at organisere det fælles liv på: den fossile kapitalisme. Her har den svenske human-geograf Andreas Malm især gjort sig bemærket med sin kritik af monistiske teorier, som han finder indenfor blandt andet den nye materialisme og aktør-netværks teorien; teorier som helt vil ophæve skel mellem menneske og natur, tanke og materie, sprog og verden.

I redaktionen har vi bestræbt os på at få møder mellem forskellige positioner til at opstå. Vi arbejdede oprindeligt med to calls i gæsteredaktionen, hvor det ene lænede mod øko-kritik og det andet mod øko-marxismen. Vi besluttede os imidlertid for at slå de to calls sammen for at skabe et sted, hvor de forskellige positioner kan tale med hinanden. Nummerets redaktion er sammensat af forskere fra 4 forskellige universiteter og 3 forskellige discipliner. I tidsskriftets bidrag er der ligeledes varierende tilgange til stoffet, både på teoretisk, empirisk, analytisk og disciplinært plan. I flere af bidragene er der fokus på den æstetiske dimension af klimadebatten med analyser af litteratur og performancekunst og hvad disses rolle er, mens andre bidrag retter sig mod politiske debatter, teoretiske problemstillinger og lokalsamfunds håndtering af konkrete udviklinger.

I temanummerets oversatte bidrag, skrevet af Amy Riddle, spiller litteraturen en central rolle. Riddle analyserer to versioner af den økologisk orienterede, litterære genre "petrofiktion"; romaner som har olie som fikspunkt. Riddles analyse fremhæver Helon Habilas roman Olie på vand's (2010) anvendelse af olie som et feticheret materiale, hvis naturlige kvaliteter vokser sammen med sin sociale form og derved skjuler de bagvedliggende samfundsmæssige forhold. Den noget ældre Byer af salt (1984) af Abdelrahman Munif finder hun derimod anderledes nuanceret i sin fremstilling af oliens sociale netværk og dynamikker. Til at underbygge sin pointe trækker Riddle på den gammelkendte litteraturteori af Georg Lukács, som skelner mellem en litteratur, der forstår og undersøger (marxistisk forståede) sociale dynamikker og historiske forandringer, og litteratur, der modsat "nøjes" med at skildre tingene som de umiddelbart fremtræder.

I artiklen "Utopisk slægtskab i udryddelsens tid" undersøger Iben Engelhardt Andersen forbindelsen mellem utopisk og økologisk tænkning. Med udgangspunkt i tekster af Inger Christensen, Donna Haraway og Hiromi Ito fremanalyserer Andersen tre forskellige bud på sammentænkninger af utopisk forestillingsevne, feministiske temporaliteter og bæredygtighed for at udvikle det argument, at selvom den dystopiske genre muligvis virker særligt relevant og oplagt i samtiden, så er der et potentiale i utopiske perspektiver, der formår at tage udgangspunkt i reproduktion, men ikke 
som en videreførelse af det eksisterende. Tværtimod tænkes reproduktion som et felt, hvor modstand, queer vækst, interartsligt slægtskab og naturens modarbejde af kapitalistisk udvikling mødes.

I Mads Ejsings bidrag kan læseren til gengæld i helt konkret forstand finde et møde mellem tre forskellige dominerende fortællinger om den globale opvarmning, nemlig øko-modernisme, øko-marxisme og ny-materialisme. Ejsing kombinerer teorierne med konkrete cases, baseret på feltarbejde i Lemvig og argumenterer dels for, at teorierne bliver stærkere i mødet med det lokale, og dels fordi at de kan, og bør, leve side om side som en del af en sund politisk diskussion.

I artiklen "Glo ikke så romantisk!" tager Elisabeth Friis og Torsten Bøgh Thomsen udgangspunkt i en skandinavisk debat omkring klimaorienteret litteratur. Imod de økocentriske, antimodernistiske og antiformalistiske litteratursyn, der har domineret debatten, undersøger de, hvordan litterære teksters formelle aspekter kan være relevante for økokritiske undersøgelser. Gennem en kontekstualiserende diskussion af debatten og analyser af to samtidige skandinaviske eksempler på økolitteratur, udvikler de argumentet, at litterær form er en af de måder, hvorigennem litteraturen forbinder sig til verden, udfordrer den og ændrer mulighederne for at tænke om den, mennesket og politik både i samtiden og i fremtiden.

Stefan Gaarsmand Jacobsen undersøger forskellige kritikker af undtagelsestilstanden i lyset af klimaaktivisters ønske om at erklære en politisk nødtilstand i klimaets navn. Disse kritikker er blevet udviklet i tandem med begreber om sikkerhedsliggørelse og afpolitisering af miljø siden 1990'erne, og Jacobsen argumenterer for, at flere teoretikere har en blind vinkel over for klimakrisens tidsperspektiv og risici for irreversibilitet i ødelagte økosystemer. Disse risici - og deres tidslighed - bør inddrages i vurderingen af diskursive problemstillinger omkring klimaaktivisters krav om en erklæring af undtagelsestilstand. Siden kritikken drejer sig om spørgsmål om suverænitet peger Jacobsen på en mere specifik analyse af suverænitetsfremtider, hvor klimarisici er determinerende, men hvor temporaliteten stadig spiller en mindre rolle.

Thomas Rosendal har i de seneste år fulgt en del af projektteatret Secret Hotels kunstneriske arbejde med at iscenesætte performative erfaringsrum og perspektiver. I sit bidrag tager han udgangspunkt i Vandrings- forelæsning om myrer produceret i 2017. Rosendals refleksion trækker på Bruno Latours tænkning om "det nye klimaregime" og Timothy Mortons teorier om miljøæstetik. Han tager skridt imod en antropocæn poetik, der på én gang kan se myren som andet end et kryb i periferien af det menneskelige synsfelt og klimaet som andet end abstrakte henvisninger til sammenhænge, der er så komplekse, at de vanskeligt kan begribes.

Slutteligt er forbindelsen mellem udviklinger i det digitale og det geofysiske fokusset i Gregers Andersens "Antropocæn og automatiseringen af adfærd". Med udgangspunkt i Felix Guattaris teori om "planetær computerisering" diskuterer han, hvordan den globale udbredelse af den personlige computer iværksætter en automatisering af adfærd, der leder til "auto-destruktiv" konsumerisme. Dette knyttes i artiklens anden del til en analyse af de danske liberale regeringers tekno-optimisme i slutningen af 2010'erne ud fra argumentet, at disse regeringer omfavnede en accelerering af automatisering uden hensyntagen til, hvordan denne ville forøge de geofysiske problemer og skabe øget ulighed.

Desuden kan du finde anmeldelser af Jonas Ross Kjærgaards Reimagining Society in Eighteenth-Century French Literature. Happiness and Human Rights, og af Mikkel Thorups Du Skylder! Om moralsk \& økonomisk gæld, i nummerets anmeldelsessektion.

Vi håber, at teksterne både kan inspirere og oplyse.

Rigtig god læselyst! 
8 KULTUR \& KLASSE $* 129 * 2020$

KLIMA, MAGT, MODSTAND 